\title{
EVALUATION OF GREEN OPEN SPACE MANAGEMENT PROGRAM IN GRESIK REGENCY BASED ON CIPP EVALUATION MODEL
}

\author{
Susilo Wati, Andy Fefta Wijaya, Suryadi \\ Email:susilo.ub@gmail.com \\ Public A dministration, Faculty of A dministrative Science-U niversity of B rawijaya
}

\begin{abstract}
Rapid industrialization gives direct impact on the environmental conditions in Gresik Regency. One attempt to maintain the balance of nature due to the rapid industrialization and rapid urban development is providing enough green open space (GOS) through GOS management program. GOS not only serves to reduce air pollution caused by pollution from existing industry, but also securing the disaster area, oxygen producer, control local climate, water resources and to improve the aesthetics of urban spatial structure. Thus it is important to provide GOS not only for healthy environment but also for sustainable development. By law number 26 of 2007 regarding the Spatial Planning in article 29 states that the proportion of green space in urban areas at least 30 (thirty) percent of the area, where the proportion of public GOS in urban areas at least 20 (twenty) percent of the area, and 10 (ten) percent for private GOS, which it is in line with Gresik local regulation no 10 of 2010 regarding Green Open Space A rrangement. This research used descriptive case study method. The design of this case study is single-case design. The single case study is analogous to a single experiment. This research was conducted in Gresik regency, East J ava Province. Gresik regency is known as industrial city in East Java. This condition gives huge impact on environmental degradation especially related to land use.
\end{abstract}

Keywords: Development, Green Open Space, Environment

\section{BACKGROUND}

In the 21th century, urban planning is facing many challenges and opportunities. In general, rapid urban development and population growth have contributed greatly to serious environmental burdens. It also happen in Gresik Regency. Large scale industrialization in Gresik makes this city has significant industrial rate, so the city is getting a lot of advantages in terms of economy. Even Gresik is awarded as the best investment award 2015 in East Java. In other hand, it gives direct impact on the environmental conditions. Gresik has the largest fertilizer company in Indonesia, cannot be denied that Gresik land has been contaminated by many chemicals. Fertilizers, pesticides, and other chemicals has been a daily consumption of community in Gresik. Indeed it will put society in unhealthy environment. These thinge led to various problems including environment damage such as environmental pollution (water, soil, and air pollution) as result of industrial activities. Nowdays industry waste causes air pollution has exceeded the threshold. Thus to minimize environment demage, government implement GOS management 
program. GOS is elongated or clustered area, the use of which is more open, where the plants grow, both naturally or deliberately planted. It is important to provide GOS not only for healthy environment but also for sustainable development. Unfortunately, the provision of GOS is hampered by massive land conversion for higher economic value tahn GOS area and also limited resources provided by government. Government plays major role in the regulation of land use in order to space utilization can deliver prosperity and protection to the people associated with the availability of urban space. This important role of government as revealed Whitehead (2007, pp. 51-52), in fact, the authority to carry out urban development to market mechanism will not bring efficient allocation of land use. This confirms that the government has a strategic role in a development area. By Law No. 26 of 2007 on Land U se create legality that space issue is an important thing that needs to be concerned in development. The availability of urban space is in contradiction with the number of inhabitants, where the population growth will decrease urban space availability. According to Haughton and Hunter, urban development in which covered elements of increasing population and welfare will impact the availability of urban space, which in turn impact on the environmental conditions (1994, p. 10).

Gresik as industrial city which directly gives negative impact toward to environment due to its waste and pollution. So, Gresik should have adequate green open space to minimize and mitigate the environmetal degradation caused by its industry activities. A s stated in Law N 0.26 Year 2007 on Spatial Planning and specified in Regulation of the $M$ inister of Public Works N o. 5 of 2008 which stated that urban spatial planning should contain the provision and utilization of green open space minimum of $30 \%$ of total area, thus it is needed to evaluate the GOS program in Gresik whether has already reached the target or not. According to Bryant and White in K uncoro (1997), the evaluation is effort to make an assessment of what happened. While according to Anderson (in A rikunto, 2004, p. 1) considers evaluation as a process to determine the results al ready achieved of planned activities. Stufflebeam and Shinkfild said that evaluations is to provide information that will help service providers regularly assess and improve services and make effective and efficient use of resources, time, and technology in order to serve the well-being and targeted needs of rightful beneficiaries appropriately and equitably (2007, p. 330). Thus researcher interested to evaluate GOS management program in Gresik as industrial city.

\section{THEORETICAL FRAMEWORK}

\section{Public Policy}

Explicitly mentioned by Thomas $R$. Dye (L ester and Stewart, 2000, p. 4) public policy is whatever governments choose to do or not to do. Quoting from Islamy (2003, p. 18), Thomas R. Dye (1975) says that if the government chose to do something it has purpose (objective) and those policies should cover all the "action" of the government, so it is not merely a government statement. In addition, something that is not implemented by the government is also can be called as policy. This is because "something was not done" by the government will have an influence (impact) as great as "something done" by government.

Today, the differentiation between agenda-setting, policy formulation, decision making, implementation, and evaluation (eventually leading to termination) has become the conventional way to describe the chronology of a policy process (Fischer, 2007, p. 43). And public policy will be detailed into programs. 


\section{Program Evaluation}

According to Fitzpatrick, et.al (2004, p. 5) define evaluation as the identification, clarification, and application of defensible criteria to determine an evaluation object's value in relation to those criteria. Nugroho (2006, p.185) says that the evaluation will provide information that is valid and reliable about the performance of policies, namely how far the needs, values and opportunities that have been achieved through public action. Objective of program evaluation is to know whether the achievement of results, progress and obstacles encountered in the implementation program can be assessed and studied for improving the implementation in the future. By evaluation will be known implementation results will be positive or negative. Evaluation will produce an objective finding which in turn will provide benefits to policy makers and related stakeholders. It is a way to prove the success or failure of the implementation of a program. One of evaluation models is CIPP (context, input, process, and product) evaluation model. This model is to determine how well a program is being implemented. The CIPP evaluation model emphasizes "learning-by-doing" to identify corrections for problematic project features. It is thus uniquely suited for evaluating emergent projects in a dynamic social context (Alkin, 2004). According to Stufflebeam and Shinkfild:

"The Context, Input, Process, and Product eval uation model has a strong orientation to service and the principles of a free society. It calls for evaluators and clients to identify and involve rightful beneficiaries, clarify their needs for service, obtain information of use in designing responsive projects and other services, assess and help guide effective implementation of service, and ultimately assess the services' merit, worth, significance, and probity." (2007, p. 330)

\section{Green Open Space}

The role and function of green open space specified in the M inister of Internal A ffairs Instruction no. 4 of 1988, which states green open space which population is dominated by either natural reforestation or cultivation as ecology function and support urban area. The role and function of green open space (GOS) specified in R egulation of the M inister of Public W orks No. 5 of 2008 article 1 states GOS which states "green open space are spaces in the city or the wider region, either in the form of area or elongated area/lane where its use more open without buildings. GOS is the total area covered by green plants in a specific unit area either naturally or cultivated. Open space can be used for city ventilation, street, sidewalk, GOS, and etc. It also can be interpreted as an interaction space such as zoo, recreation parks

\section{RESEARCH METHOD}

This research used descriptive case study method. Case study is an empirical inquiry that investigates a contemporary phenomenon in depth within its real life context ( $Y$ in, 2009, p.18). The design of this case study is single-case design. The single case study is analogous to a single experiment, and many of the same condition that justify a single experiment also justify a single case study ( $Y$ in, 2009, p. 47). The focuses of this research are:

1. GOS management program to increase GOS area in Gresik Regency, this focus describes the output of GOS management program from 2011 until 2015.

2. Factors affecting GOS provision in Gresik Regency

a. Input of GOS management program (budget, human resource, information and land provision) 
b. Process of GOS management program (planning and implementation process)

c. Context of GOS management program (social condition in Gresik R egency)

This research was conducted in Gresik regency, East J ava Province. Gresik regency is known as industrial city in East Java. This condition gives huge impact on environmental degradation. A nd the site of this research in Badan Lingkungan Hidup $(B L H)$ in Gresik regency where GOS management program is carried out.

\section{RESULT AND DISCUSSION}

\section{Result}

\section{GOS management program to} increase GOS area in Gresik Regency

The identification of public GOS in Gresik regency based on existing condition consist of city parks, recreation parks, hills/mountains, green line: border of river bank, railway border line, around high voltage area, grave, open parking and sports field. Here is the percentage of green space in G resik today:

Table 1 Percentage of Green Open Space in Gresik Based on Interpretation Image 2015

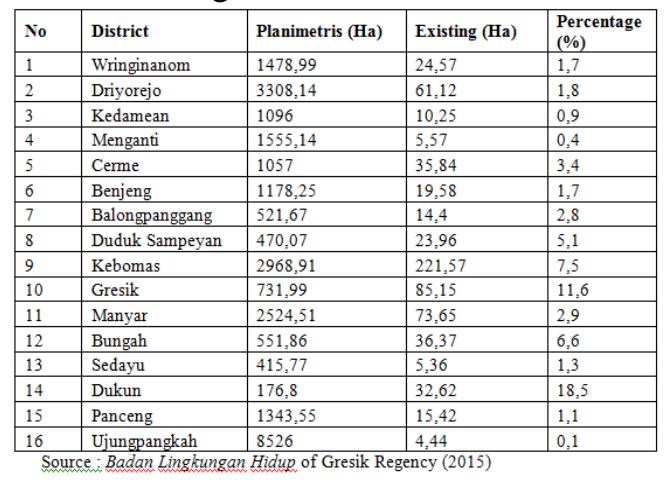

So far public GOS in G resik is still far from $20 \%$ as mandated in the regulations. In fact, no one sub district able to meet the regulation. Moreover the construction of green space as urban park focused on two sub districts, namely Gresik and Kebomas sub district. It can be seen the small scope of public GOS handled by BLH whereas according to Medium Term of Local Development (RPJMD), BLH is obliged to provide and manage a public green space in all G resik districts.

\section{Factors affecting GOS provision in Gresik Regency}

\section{a. Input of GOS management program}

There was budget fluctuation in each year. It was because of development priority in other sectors. Percentage of allocation for GOS management program in BLH was more than $30 \%$ of the overall budget annually.

There was also inhabitant of human resources. So far GOS management program only rely on out sourcing, from the park construction until the maintenance. So this is also the reason why until now BLH could only focus on two sub districts in urban centers. Budget constraints also become an important factor that cannot increase the number of available human resources. The lack of functional human resources in the technical implementation of GOS management program in Gresik becomes obstacles. In addition, in the level of field implementer, there are no human resources who are qualified on environment discourse. Overall of them are unskilled who just served as the execution of the construction and maintenance of existing green space in Gresik R egency.

Besides, human resource, data also become input in this GOS management program. Until 2015, the implementation of GOS management program is plagued by the presence of valid data. Thus the implementation of the program so far only focus on the fulfillment of the central green space in urban areas. The absence of GOS master plan also be obstacle related to the planning system of GOS 
management program. The invalid data become obstacle in planning system.

In terms of land availability so far also become the main obstacle. Although the spatial planning of Gresik Regency has been mentioned the allocation for GOS but in fact there is no specific land that has been provided by the government for this program. Despite in RPJMD provision of green open space program has become a priority, but in reality the industrial city that has been attached to Gresik, lead governments more focus on the industry development rather than the provision of land for green space. It can be conclude that from input aspect, there is lack of resources to support GOS managemnet program. The minimum budget, lack of human resources and land also invalid data become obstacle. Thus it will hamper the next process in this program.

\section{b. Process of GOS management program}

GOS target fulfillment as stated in A ct 26 of 2007 on Spatial Planning are $20 \%$ of the urban area. The provision will be foundation of obligatory functions of local government to set up M inimum Service Standards. Planning of GOS management program is in line with the vision and mission of BLH in Gresik Regency as well as medium term of local development planning. In its capacity as a local unit in Gresik Regency, BLH of Gresik Regency has a duty to "Organizing Local Household Affairs and Tasks Assistant in the Environment".

Increasing green open spaces area is the implementation of fifth mission, which enhances the beauty and quality of the environment through compliance with open green spaces and urban facilities with the aim of improving the cleanliness and beauty through environmental management, structuring the city and open green spaces. From an organizational level, the GOS management program has become a priority of the organization, this is evidenced by $\mathrm{BLH}$ budget allocation of more than $30 \%$ was allocated for the implementation of this program. Unfortunately in the higher organizational levels, GOS management program is no longer being priority.

To carry out its activities, BLH is working with other officials to increase public GOS in Gresik. The sharing duties and functions are clear between the parties involved in the success of GOS management program would be an absolute requirement in order to avoid overlapping tasks. In practice there are some technical obstacles that ultimately hinder the implementation. For example, the Department of A griculture, Plantation and Forestry Department of Gresik Regency is not always able to support the provision of seeds because it also has a similar program, the Agency for Investment and Licensing in Gresik less control of the industry which al ready built the industry based on site plan or not. So that today there are many industries that do not meet the criteria of $20 \%$ provision of green space in industrial areas. Although many officials unit involved, most of the cooperation undertaken in this program is still within the scope of cooperation in internal local government of Gresik. So, in the planning and implementation process, this program run as usual based on the procedure.

\section{c. Context of GOS management program}

Participation and community support for the program is also a determinant of success. From the results of civil registration shows that the number of inhabitants in Gresik in 2014 amounted to $1,319,314$ people, consisting of 664.288 men's and women's 655.026. The total population is at 370.363 families. With an area of $1191.25 \mathrm{~km}^{2}$ Gresik has a population density of 1,108 people/ $/ \mathrm{km}^{2}$. 


\begin{abstract}
Providing sufficient green space is very important to maintain the environmental balance and gives the right to every citizen in Gresik to get clean air. With Gresik position as an industrial city and hinterland of Surabaya City will tend to accelerate the growth of population in Gresik regency. Rapid population growth leads to greater population growth. It also affects the extent of green space should be provided. Unfortunately BLH gives less opportunity for community to participate in GOS management program, so some environmental ist reluctant to cooperate and engage. This lack cooperation between $\mathrm{BLH}$ and community resulting this program marely belong to the government. There is low sense of belonging from the community because they are not involved by $\mathrm{BLH}$ in this program.
\end{abstract}

\section{Discussion}

\section{GOS management program to} increase GOS area in Gresik Regency

The product of GOS management program has not reached the target yet. It can be seen if the public GOS management program still far from the regulation. Product evaluation is aimed to determine the expected results of a program. It also to determine whether the results were achieved in line with the plan and to determine the success of program can be assessed by its effectiveness. Effectiveness shows the extent to which achievement of specified goal. Effectiveness is description of the extent to which the output of an activity can achieve the goals that have been set. Meanwhile, according to Gie (2000, p. 24), explains that effectiveness was defined as the degree of organization to realize its goals.

The problems of inadequate of public GOS is to pursuit of economic growth without considering natural resources and the environment. Besides the quantity cannot be fulfilled ideally, it seems in terms of GOS quality locations in G resik is still not evenly distributed. If seen from the results of the year (2011-2015), GOS management program in Gresik Regency only focused on two sub districts, namely K ebomas and Gresik sub district which are as the main urban center in Gresik. Its position as the urban centers and the location is also closer to BLH office than other sub districts, makes these district as the central of GOS management program. Because these sub districts are the representation of Gresik Regency as a whole.

This condition is in line with Perroux idea related to growth pole theory. In his theory he stated that the development do not occur in all areas, only limited to some areas as development pole, and mostly this development is pushed by the existence of large scale industry (A disasmita, 2008, p. 39). And these industries will be leading development for the next. Growth pole is a place where there are key industries that play important role as a dynamic driving factor because the industry has ability to innovate. A growth poles can be an industrial complex grouped around key industries. In Gresik Regency, the existence of PT Petrokomia, Ltd and Semen Indonesia as the biggest industry which exist in Kebomas and Gresik Sub district makes both of these two sub district become the center pole of development in G resik.

\section{Factors affecting GOS provision in Gresik Regency}

\section{a. Input of GOS management program}

Related to input aspect, there is lack of resources to support GOS management program. The minimum budget, lack of human resources and land also invalid data become obstacle. Budget is one part of management control process which contains annual plan, stated quantitatively, and measured in monetary terms. If seen from year-to-year budget in GOS management program was fluctuated. It based on local government allocation for 
BLH. Besides the allocation of funds also depends on development priorities in Gresik Regency. Currently the GOS management program in Gresik was not as main priority yet in the development so the allocated budget was still minimal. Budget support is limited because it depends on the ceiling budget of BLH Gresik so must constantly keep its efficiency. The budget for GOS management program only depend on local budget. The lack of budget disbursed by local government lead to lack infrastructure of green open space in Gresik. This of course makes the complex problem of GOS management program. BLH could actually cooperate with the company in Gresik to channel its Corporate Social Responsibility (CSR) program on the improvement of green open space to deal with limited budget. B ut CSR now rarely used for the provision of green space because the impact is less strategic on the company's image. The majority of the company's CSR program is used for direct assistance to communities in the form of soft loans or community empowerment. So BLH is still struggling to get financial support from private parties in order to support GOS management program in Gresik. It also will affect the availability of the human resources in the implementation of this program.

Besides budget, in an organization, human resources are one resource that is essential in the process of achieving organizational goals. Executive element is the implementers of a program described by Dimock in Tachjan (2006, p. 28), implementer are pursuing a policy which consists of setting goals and targets organizational, analytical and formulation of policies and strategies of the organization, decision-making, planning, programming, organizing, mobilizing the human resource, operational implementation, monitoring and assessment. Their limited human resources of GOS management program lead to hamper the process of implementation of green space in Gresik. Technical human resources in implementation is still not sufficient. As outsourcing labor with the payroll system based on working hours. Due to limited funds, to implement this program, the human resources employed only at certain times based on need. The other problem is incompetence human resources. Almost all of technical workers have no background about spatial.

Land also becomes important input for GOS management program. Land management holds a crucial role in the development of cities which rapid economic growth happen as Gresik Regency. Land conversion takes place more quickly in order to achieve economic growth but has caused environmental damage. The increasing competition and land conversion lead conflict of interest between the land users with society to reside in the city.

Actually, when viewed from the Spatial Planning 2010-2030 in Gresik, local government has allocated land for GOS area. But the fact that until now has not been realized. And if it is seen from medium term of local development planning (RPJMD) which has been stated in long term of local development planning (RPJPD), indeed for the 2011-2015 period is still focused on the industry development. But for sustainable development reflected by sustainable support of the environment and recovery capabilities to support the social quality and economic will be realized in the period 2016-2020. In 2011-2015 the focus is industry development. Governmet create friendly industry climate and give space for massive industry but sacrificing environment which is neglecting GOS provision. In this case show that there is goal conflict in Gresik development which known as incompatible goal conflict. According to Ritzer and Goodman (2004, p. 157) conflict is part of social reality which creating development and change. And the change its self is government prioritize land for industry than GOS. 
And the last is the availability of data. Development planning which use good data quality and up-to-date will give a direction closer to the target. The issue of 'obsolete' data (perhaps a little better than no data at all) often experienced by many people who are always using the data in the planning stage. It is also experienced by $\mathrm{BLH}$ in the implementation of GOS management program in Gresik. So far the data used by BLH arguably was not up to date. Until 2015 B L H has no model of land information systems, and accurate mapping systems to monitor the existing GOS, some numbers that are erased, and other information that is necessary for "decision makers" as well as the needs of other activity.

\section{b. Process of GOS management program}

Planning and implementation process of GOS management program run as usual based on the procedure. GOS management program in Gresik included in the development in the field of environment implemented by BLH Gresik in Division of beauty environment, in particular subfield of Parks and environmental decoration. GOS management program is the realization of sustainable development in Gresik. Evaluation of GOS management program process is to determine compatibility between planning and execution of the program.

Although planning and implementation stage run as usual and in line with the existence procedures but because of there are several lack of sources as mentioned in input of the program, it obviously give impact to planning and implementation stage, in the end it affects the result of this program, which is inadequate GOS in Gresik Regency. So, it can be conclude as failed policy because it cannot fulfill the desired outcome which is $20 \%$ area of public GOS. Based on opinion stated by M cC onnell (2010, p. 237), policy fails, even if it is successful in some minimal respects, if it does not fundamentally achieve the goals that proponents set out to achieve, and opposition is great and/or support is virtually non-existent. More recently, a major book on 'policy blunders' in the UK by King and Crewe (2013) is an empirically focused examination of many policy failures in the UK, their definition of a 'blunder' alludes to degrees of failure while also touching on the policy failure.

\section{c. Context of GOS management program}

There is lack cooperation between $\mathrm{BLH}$ and community in GOS management program, thus this program merely belongs to the government. In the end, there is low sense of belonging from the community because they are not involved by BLH to participate. While the success of public organizations cannot be separated from an interactive relationship with their social environment. The failure of social interest's adoption is the same with ignoring the interests of the majority stakeholders.

Sumaryana (2010) illustrated that the slow motion of many public activities in providing services to the community can show their ignorance of social environment that is dynamic and critical. The increasing of society's education greatly contributes to the increasing knowledge which needs to be responded by policy implementer. Discrimination in services could create negative impact on the survival of public organizations. Therefore, needs to change communication strategies between government and communities as stakeholders. It also happens to GOS management program in Gresik. So far the density of population in Gresik is often overlooked as a potential that can be used to support the program implementation.

Muller (2006, p. 256) emphasizes that all development will succeed if it is run not only for but also with and by communities. Communities must participate actively to 
define the programs thus determine the circumstances of their own lives, starting from decision stage, and not just on the implementation. According to Warner (2014, p. 30), if projects take economic issues into consideration, they are able to gain more acceptance at the stakeholder level, higher incomes would have an immediate effect. Thus there must be added value to attract community participation in GOS management program in Gresik Regency.

\section{CONCLUSION}

Product of public GOS management program in the period of 2011-2015 has not reached the standard yet. And so far since 2011 till 2015 BLH focus on the development of public GOS two sub districts. So in terms of the program results are still concentrated in urban centers. Thus there are still inequality results from GOS management program conducted by BLH of Gresik Regency. This condition due to lack of resources (land, budget, valid data, and also human resources) in planning and implementation stage. Thus, It can be conclude as failed policy because it cannot fulfill the desired outcome which is $20 \%$ area of public GOS. In other hand, from the context of social aspect, high density of population in Gresik has not utilized yet by $B L H$ to engage in GOS management program. BLH give less opportunity to participate in the program management of green open space.

\section{REFERENCES}

Alkin, M.C. 2004. Evaluation Roots: Tracking Theorists' Views And Inflences. Thusand

A rikunto, Suharsimi. 2004. Dasar-Dasar Evaluasi Pendidikan. Jakarta:B umi A ksara
Fischer, T. 2007. Theory and Practice of Strategic Environmental Assessment. Towards a more systematic approach. London: Earthscan

Fitzpatrick et,al, 2004. Program Evaluation: Alternative Approach and Practical Guideline (third Edition). USA :Pearson

Haughton, Graham and Hunter, Colin. 1994. Sustainable Cities. London:J essica Kingsley Publisher Ltd.

Islamy, M IIfan. 2003. Prinsip-prinsip Perumusan Kebijakan Negara. J akarta:Bumi A ksara

King, A and Crewe, I .2013. The Blunders of Our Governments. London: Oneworld

Kuncoro, Mudrajad. 1997, Ekonomi Pembangunan, Teori Masalah dan Kebijakan. Y ogyakarta:Y K PN

Muller, Johannes. 2006. Perkembangan Masyarakat Lintas Ilmu. J akarta:G ramedia Pustaka U tama

Nugroho, Riant. 2006. Kebijakan Publik untuk Negara-Negara Berkembang. Jakarta:PT Elex M edia Komputindo

Ritzer, George and Goodman, Douglas J. 2004. Teori Sosiologi Modern. Jakarta: Prenada M edia

Stufflebeam, D. L., Shinkfild, A. J. 2007. Evaluation Theory, Models, \& Applications. San Francisco, CA: J ossey-B ass.

Sumaryana. 2010. Lingkungan dan Tata Ruang di Bandung Utara. Bandung: Unpad Press

Tachjan. 2006. Implementasi Kebijakan Publik. Bandung: AIPI dan Puslit $\mathrm{KP} 2 \mathrm{~W}$

Warner, Cosima. 2013. Green Open Spaces in Indonesian Cities: schisms between law and practice. Department of Geography, FriedrichA lexander-U niversity:Germany

W hitehead, C. 2007. Planning Policies and Affordable Housing: England as a successful case study? Housing Studies 
Y in, R obert K. 2009. Case study Research:

Design and Methods (Fourth Edition).

California:Sage 